Supporting information

\title{
Visible Light Promoted Generation of Hydrogen from the Hydrolysis of Silanes Catalyzed by Rhodium(III) Porphyrins
}

Mengmeng $\mathrm{Yu}^{\dagger}$, Huize Jing ${ }^{\dagger}$, Xu Liu, Xuefeng Fu*

Beijing National Laboratory for Molecular Sciences, State Key Lab of Rare Earth Materials Chemistry and Applications, College of Chemistry and Molecular Engineering, Peking University, Beijing 100871, China

\section{Contents}

$\begin{array}{lr}\text { NMR and IR Spectra of (TAP)Rh-I } & \text { S2 }\end{array}$

$\begin{array}{ll}\text { NMR Spectra of (TAP)Rh-H } & \text { S4 }\end{array}$

Catalytic hydrolysis of $\mathrm{EtMe}_{2} \mathrm{SiH}$ by (TAP)Rh-I $\quad$ S5

$\begin{array}{ll}\text { NMR and HR-MS Spectra of (TAP)Rh-SiEtMe } & \text { S6 }\end{array}$

$\begin{array}{ll}\text { Effect of } \mathrm{I}^{-} & \text {S8 }\end{array}$

$\begin{array}{ll}\text { Effect of } \mathrm{H}^{+} & \text {S8 }\end{array}$

$\begin{array}{ll}\text { NMR Spectra of }[(\mathrm{TAP}) \mathrm{Rh}]_{2} & \text { S9 }\end{array}$

${ }^{\dagger} \mathrm{M}$. Yu and H. Jing contributed equally to this work 
I. $\quad{ }^{1} \mathrm{H}$ NMR and IR Spectra of (TAP)Rh-I
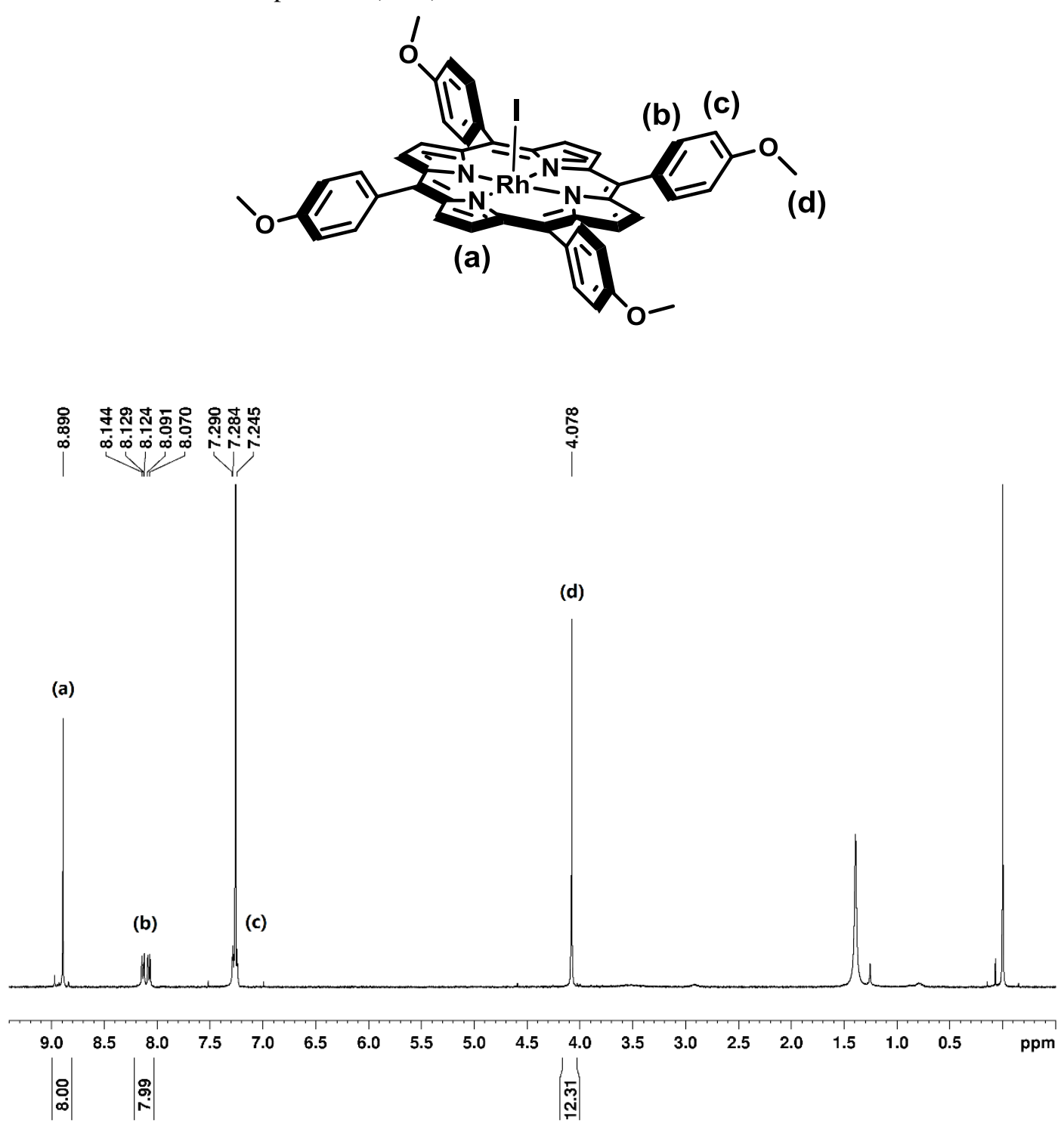

Figure S1 ${ }^{1} \mathrm{H}$ NMR spectrum of (TAP)Rh-I (400 $\left.\mathrm{MHz}, \mathrm{CDCl}_{3}\right)$.

${ }^{1} \mathrm{H}$ NMR (400 MHz, $\left.\mathrm{CDCl}_{3}\right) \delta(\mathrm{ppm}): 4.08\left(\mathrm{~s}, 12 \mathrm{H} ; \mathrm{CH}_{3}\right), 7.24-7.29(\mathrm{~m}, 8 \mathrm{H} ;$ meta-H),

8.07-8.14 (m, $8 \mathrm{H}$; ortho-H), 8.89 (s, $8 \mathrm{H} ; \beta$-pyrrole $\mathrm{H}) .7 .26$ for chloroform, 1.39 for water. 
a

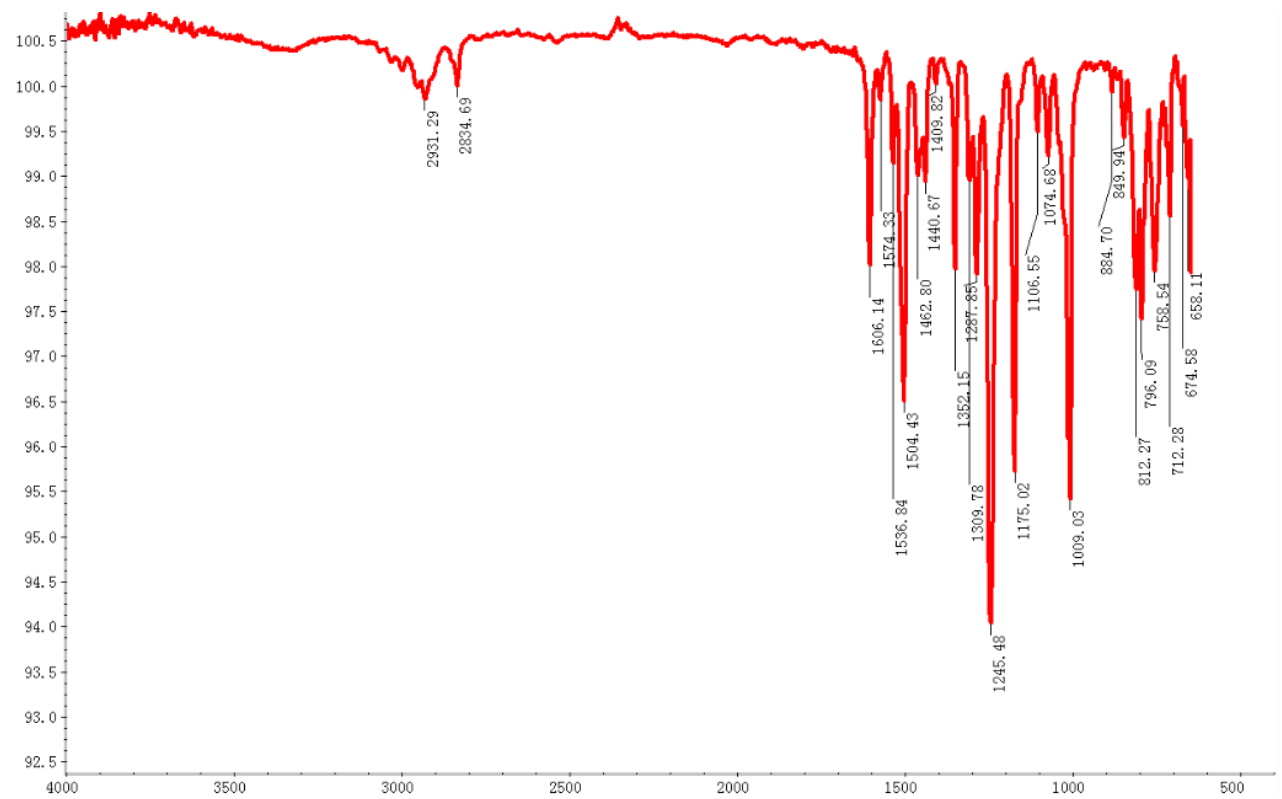

b

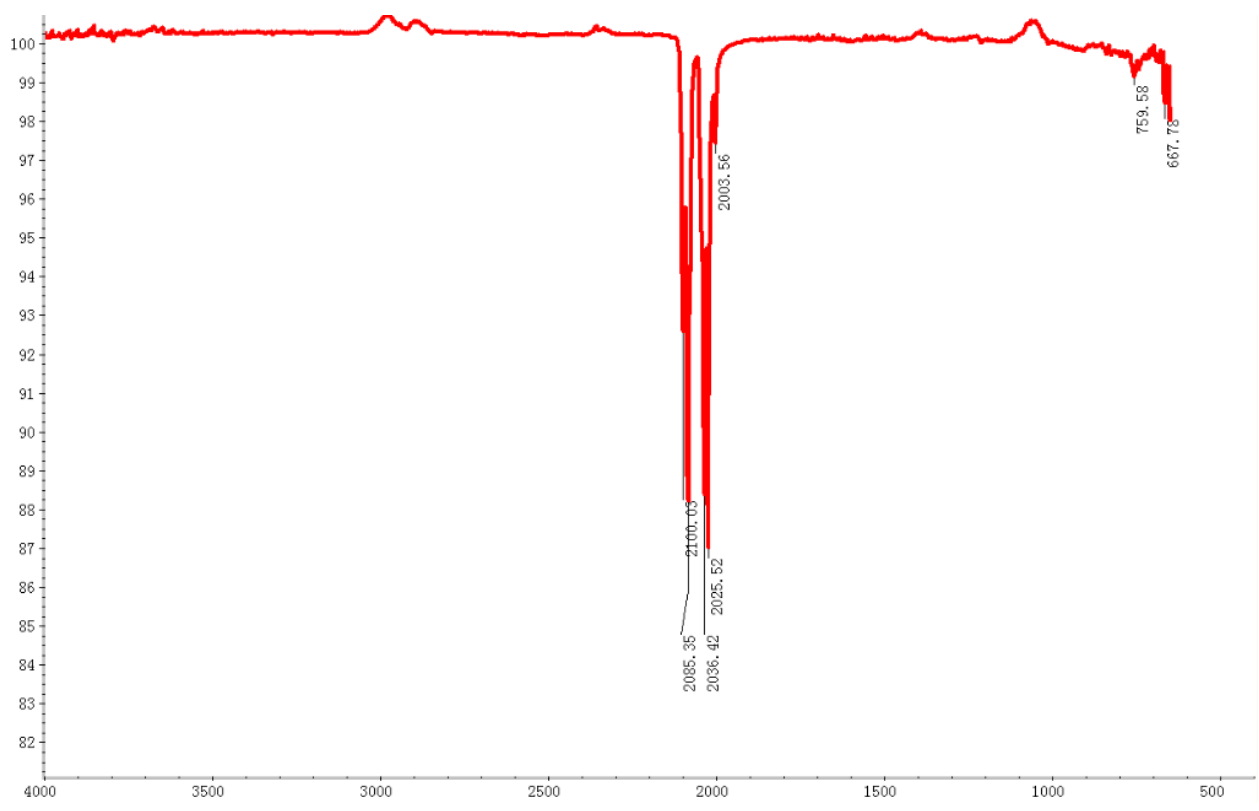

Figure S2 IR spectrum of (a) (TAP)Rh-I (b) $\left[\mathrm{RhCl}(\mathrm{CO})_{2}\right]_{2}$, $x$-axis for wavenumbers and $\mathrm{y}$-axis for transmittance. $\mathrm{No}\left[\mathrm{RhCl}(\mathrm{CO})_{2}\right]_{2}$ remained in the catalyst. 
II. $\quad{ }^{1} \mathrm{H}$ NMR Spectra of (TAP)Rh-H
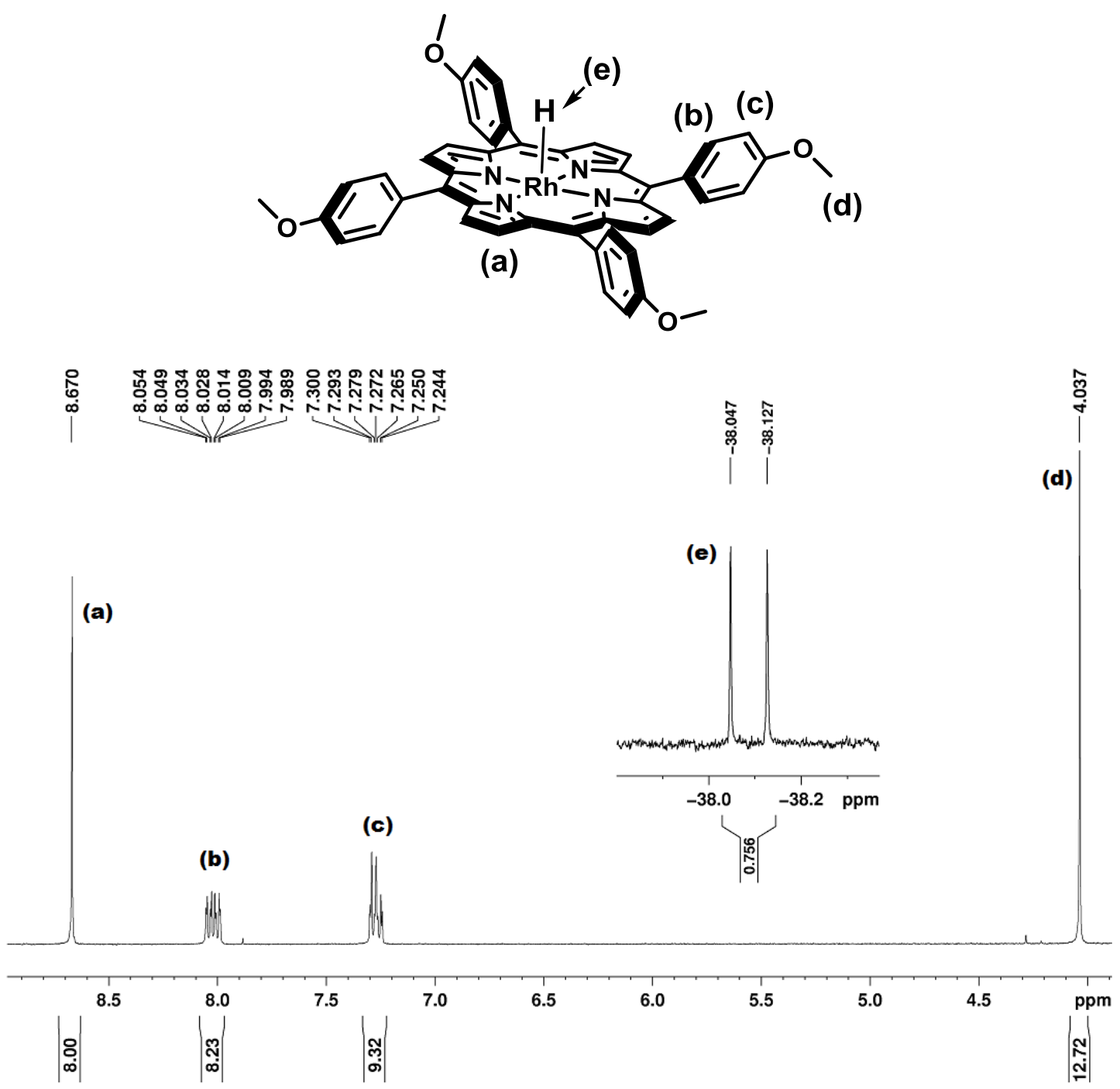

Figure S3 ${ }^{1} \mathrm{H}$ NMR spectrum of (TAP)Rh-H in THF- $d_{8}$.

$\delta(\mathrm{ppm}):-38.09\left(\mathrm{~d}, 1 \mathrm{H},{ }^{1} J(\mathrm{Rh}, \mathrm{H})=31.7 \mathrm{~Hz} ; \mathrm{Rh}-\mathrm{H}\right), 4.04\left(\mathrm{~s}, 12 \mathrm{H} ; \mathrm{CH}_{3}\right), 7.24-7.30(\mathrm{~m}, 8 \mathrm{H} ;$ meta $-\mathrm{H})$, 7.99-8.05 (m, 8H; ortho-H), 8.67 (s, 8H; $\beta$-pyrrole $\mathrm{H}$ ). (Residual solvent at 7.29 ppm caused the integral of 7.24-7.29 ppm larger than 8.00.) 
III. Catalytic hydrolysis of EtMe $\mathrm{SiH}_{2}$ by (TAP)Rh-I

a

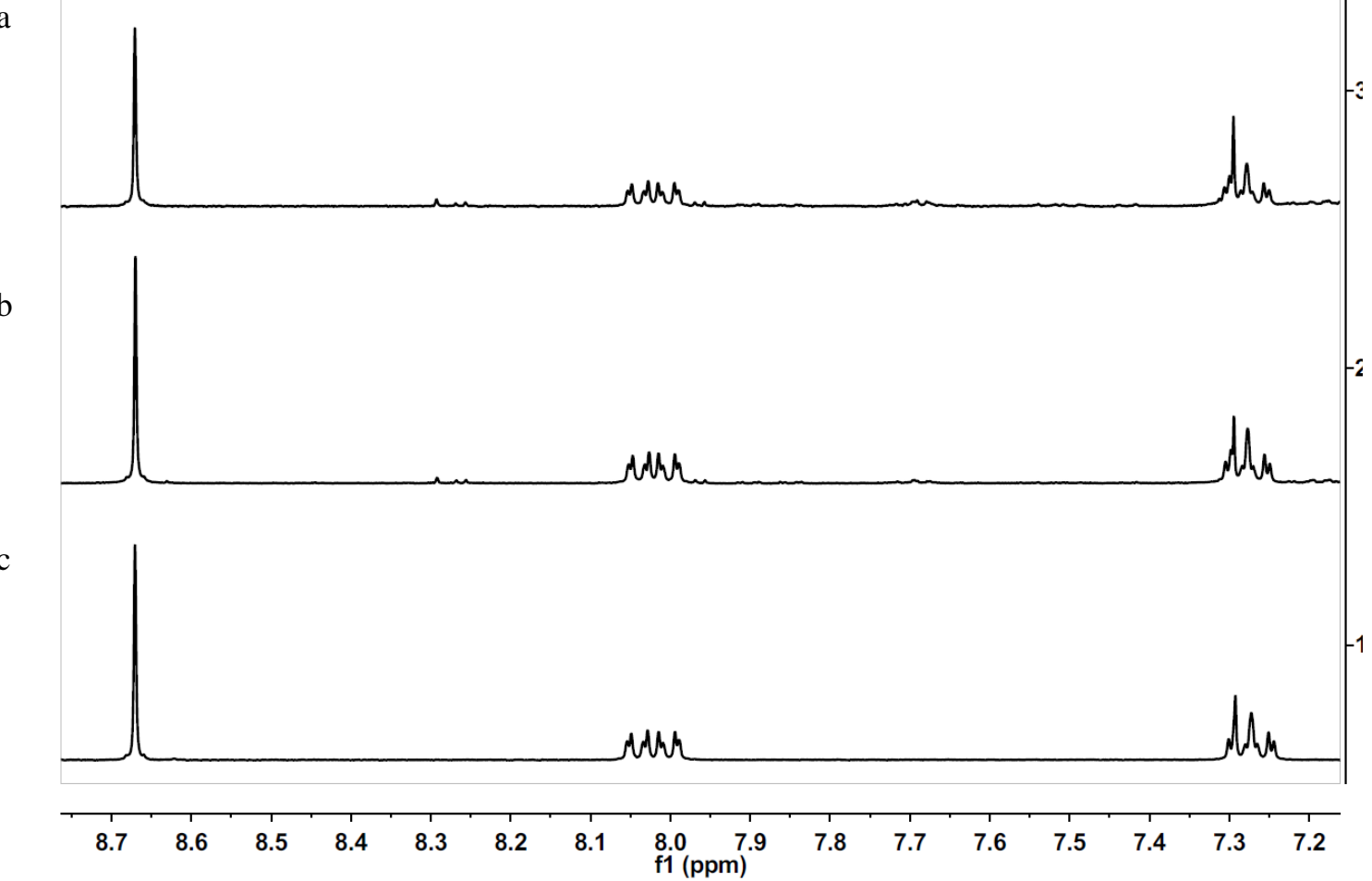

Figure S4 (TAP)Rh-H is the resting state of the catalyst. No obvious changes observed in ${ }^{1} \mathbf{H}$ NMR spectra during the catalytic reaction in THF- $d_{8}$. a). before irradiation; b). irradiation for $1 \mathrm{~h}, 86 \%$ silane remained; c). irradiation for $5.3 \mathrm{~h}, 39 \%$ silane remained. 
IV. $\quad{ }^{1} \mathrm{H}$ NMR and HR-MS Spectra of (TAP)Rh-SiEtMe ${ }_{2}$
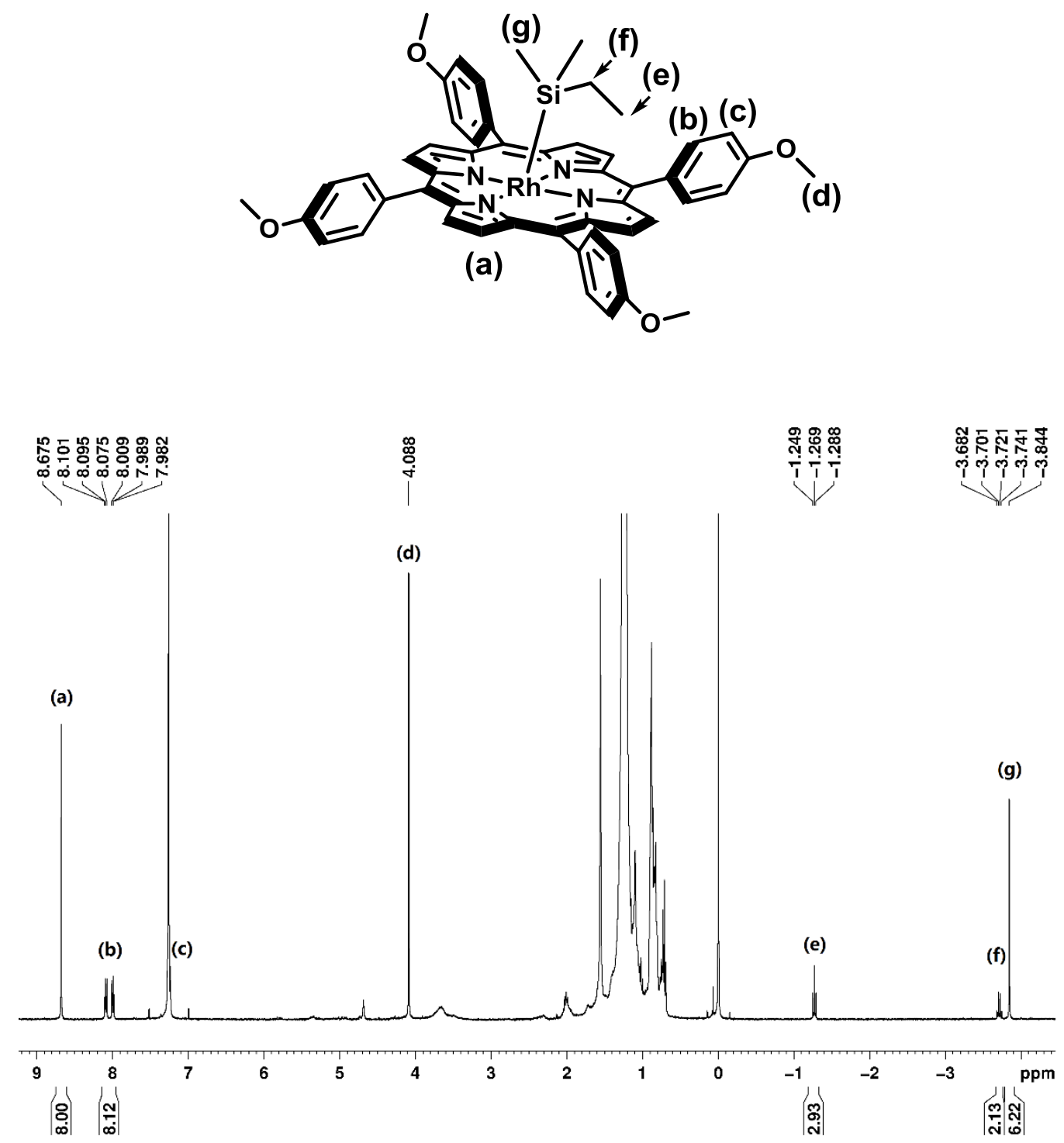

Figure $\mathrm{S5}{ }^{1} \mathrm{H}$ NMR spectrum of (TAP) Rh-SiEtMe ${ }_{2}$ in $\mathrm{CDCl}_{3}$.

$\delta(\mathrm{ppm}):-3.84\left(\mathrm{~s}, 6 \mathrm{H}\right.$; methyl $\left.\mathrm{CH}_{3}\right),-3.71\left(\mathrm{q}, 2 \mathrm{H},{ }^{3} J(\mathrm{H}, \mathrm{H})=7.9 \mathrm{~Hz} ; \mathrm{CH}_{2}\right),-1.27\left(\mathrm{t}, 3 \mathrm{H},{ }^{3} J(\mathrm{H}, \mathrm{H})=8.0\right.$ $\mathrm{Hz}$; ethyl $\left.\mathrm{CH}_{3}\right), 4.09$ (s, 12H; $\left.\mathrm{OCH}_{3}\right)$, 7.23-7.28 (m, 8H; meta-H) , 7.98-8.10 (m, 8H; ortho-H), 8.67 ( $\mathrm{s}, 8 \mathrm{H} ; \beta$-pyrrole $\mathrm{H}$ ). The peaks not labeled are signals of residual solvents. 


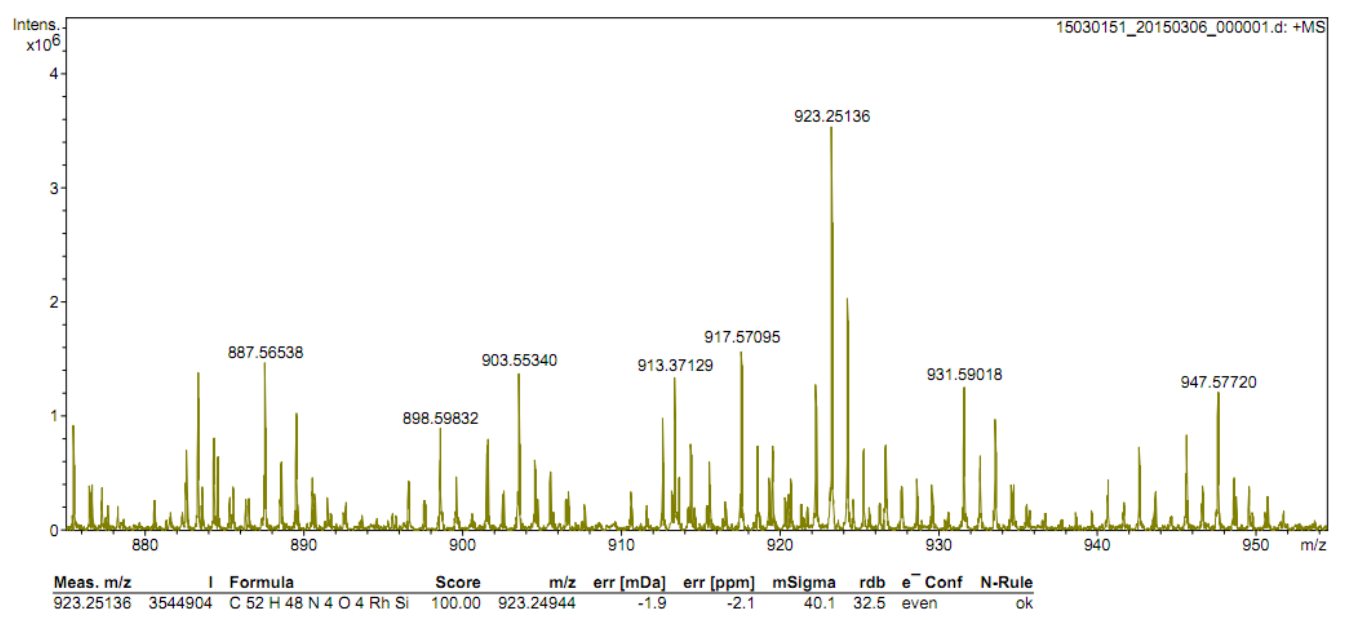

Figure S6 HRMS (ESI) spectrum of (TAP)Rh-SiEtMe 2 HRMS (ESI) calcd for $\mathrm{C}_{52} \mathrm{H}_{48} \mathrm{~N}_{4} \mathrm{O}_{4} \mathrm{RhSi}[\mathrm{M}+\mathrm{H}]^{+}$923.25136; found 923.24944. 
Table S1.Hydrolysis of $\mathrm{PhMe}_{2} \mathrm{SiH}$ Catalyzed by (TAP)Rh-I with various amounts of $n$-Bu ${ }_{4} \mathrm{NI}$

\begin{tabular}{c|ccc}
\hline & Time $(\mathrm{h})$ & $\mathrm{H}_{2}(\%)$ & Yield $(\%)$ \\
\hline No additional I & 1.5 & 95 & $>95$ \\
0.5 eq of $n-\mathrm{Bu}_{4} \mathrm{NI}$ & 1.5 & 86 & 91 \\
1 eq of $n-\mathrm{Bu}_{4} \mathrm{NI}$ & 1.5 & 53 & 50 \\
10 eq of $n-\mathrm{Bu}_{4} \mathrm{NI}$ & 1.5 & 32 & 39 \\
250 eq of $n-\mathrm{Bu}_{4} \mathrm{NI}$ & 1.5 & 35 & 45 \\
\hline
\end{tabular}

Table S2.Hydrolysis of $\mathrm{PhMe}_{2} \mathrm{SiH}$ Catalyzed by (TAP)Rh-I with $\mathrm{CF}_{3} \mathrm{COOH}$

\begin{tabular}{c|ccc}
\hline & Time $(\mathrm{h})$ & $\mathrm{H}_{2}(\%)$ & Yield(\%) \\
\hline No additional $\mathrm{H}^{+}$ & 1.5 & 95 & $>95$ \\
1 eq of $\mathrm{CF}_{3} \mathrm{COOH}$ & 1.5 & 92 & 95 \\
No (TAP)Rh-I, 125 eq of $\mathrm{CF}_{3} \mathrm{COOH}$ & 1.5 & 5 & trace \\
\hline
\end{tabular}




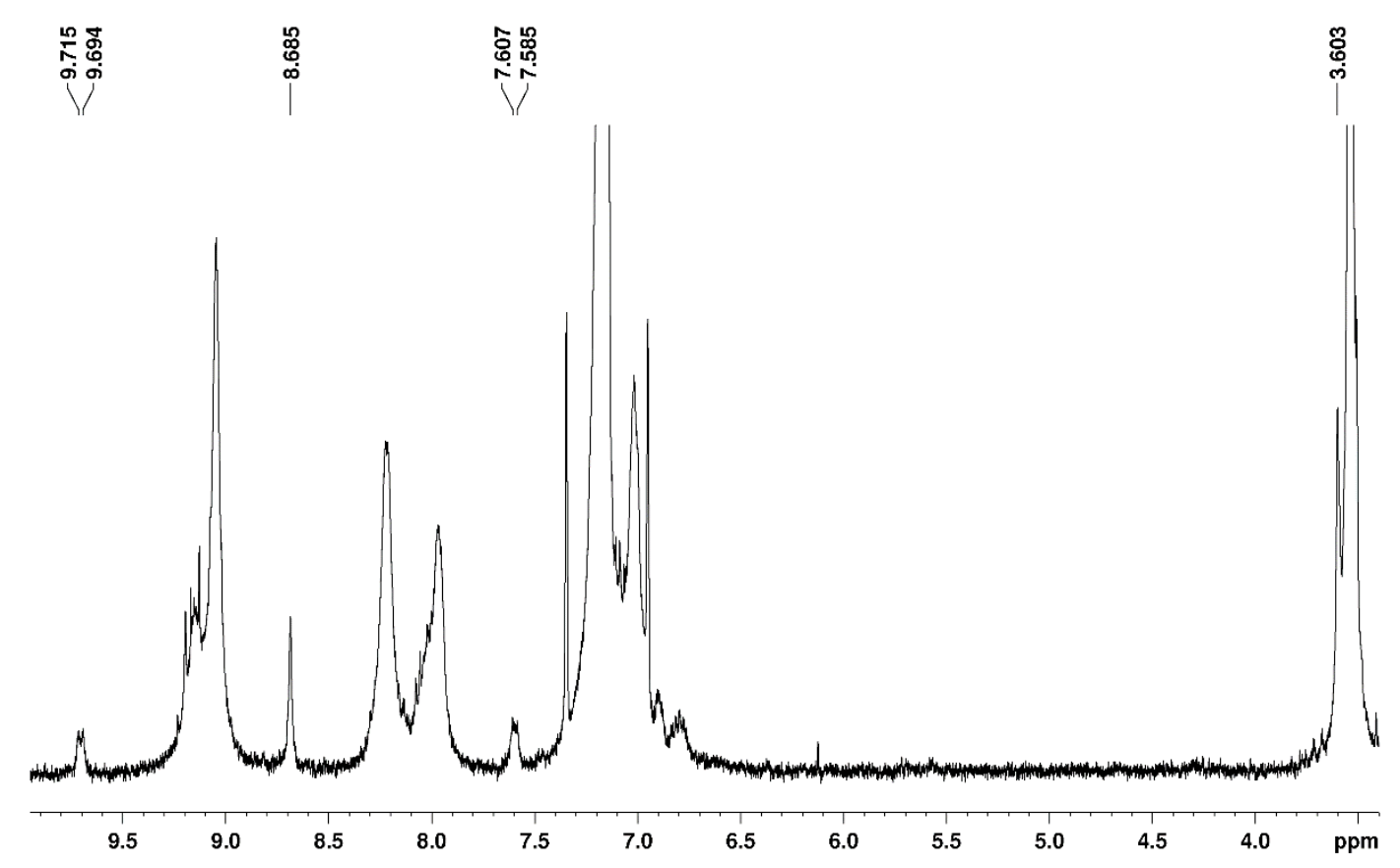

Figure S7. Generation of [(TAP)Rh $]_{2}$ dimer in the photolysis of (TAP)Rh-H ${ }^{1} \mathrm{H}$ NMR (400 MHz, $\mathrm{C}_{6} \mathrm{D}_{6}$ ) $\delta(\mathrm{ppm}): 3.61$ (s, 24H; $\mathrm{CH}_{3}$ ), 7.15 (meta-phenyl $\mathrm{H}$ are obscured by solvent), $7.60\left(\mathrm{~d}, 8 \mathrm{H},{ }^{3} \mathrm{~J}(\mathrm{H}, \mathrm{H})=7.4 \mathrm{~Hz}\right.$; ortho-H), $8.69(\mathrm{~s}, 16 \mathrm{H} ; \beta$-pyrrole $\mathrm{H}), 9.70\left(\mathrm{~d}, 8 \mathrm{H},{ }^{3} J\right.$ $(\mathrm{H}, \mathrm{H})=7.8 \mathrm{~Hz} ;$ ortho $-\mathrm{H})$. 